\title{
The use of larvae and pupal exuviae to study the biodiversity of Chironomidae in Mediterranean streams
}

\author{
N. Prat, T. Puntí, M. Rieradevall† \\ Freshwater Ecology and Management Research Group, Department of Ecology, University of \\ Barcelona, Barcelona, Spain
}

\begin{abstract}
A total of 100 larval and 101 pupal taxa were found belonging to 60 and 36 genera, respectively, in 25 river sites in Catalonia (NE Spain). If we correct for the total number of individuals examined (7629 larvae, 1589 pupal exuviae) the number of genera per 100 individuals is 0.84 for larvae and 2.26 for pupal exuviae and the number of taxa per 100 individuals 1.40 and 6.10 , respectively. The following points explain why a similar number of taxa have been found for larvae and pupae (despite the large difference in the number of genera): i) difficulties in differentiating the larvae species, especially in some complex rich and frequent genera, such as Cricotopus-Orthocladius (only six taxa as larvae but 31 as pupae); ii) many (24) larval genera were not found as pupae (even two subfamilies) while only three genera where found only as pupal exuviae. This is because of the larger number of larvae examined, but also because not all the larvae present at one site had emerged at the time of sampling. Given the difficulties in classifying the larvae to species level, the collection of pupae remains a useful method to complement quantification of chironomid biodiversity in a region; until massive DNA-sequencing of field samples of such invertebrates will be possible and easily available to many researchers (especially those in low income countries).
\end{abstract}

Correspondence: Narcís Prat, Freshwater Ecology and Management (F.E.M.) Research Group, Department of Ecology, University of Barcelona, Diagonal, 643, 08028 Barcelona, Spain.

Tel.: +34934037139.

E-mail: nprat@ub.edu

Key words: Chironomidae; larvae; pupal exuviae; taxonomy; biodiversity.

Acknowledgements: we would like to thank Núria Sánchez-Millaruelo for the preparation of the slides. This is a contribution to the Projects GUADALMED HID98-0323-C05 and REN2001-3438-C07 from the Spanish Ministry of Science and Technology, which provided us with the financial support for this project.

Received for publication: 22 September 2015.

Accepted for publication: 21 October 2015.

(c) Copyright N. Prat et al., 2016

Licensee PAGEPress, Italy

Journal of Entomological and Acarological Research 2016; $48: 5529$

doi:10.4081/jear.2016.5529

This article is distributed under the terms of the Creative Commons Attribution Noncommercial License (by-nc 4.0) which permits any noncommercial use, distribution, and reproduction in any medium, provided the original author(s) and source are credited.

\section{Introduction}

Chironomidae is a group of globally distributed aquatic Diptera frequent and abundant in many freshwater habitats, where they often constitute the basic food for many organisms (Armitage et al., 1995). There are more than 4147 described species of chironomids (Ferrington, 2008). Species identification is based mostly on the male adult genitalia, sometimes in collections using light traps (Hirabayashi et al., 2010). The use of larvae is infrequent for biodiversity studies; nevertheless, they are very important for ecological studies as, sometimes, $50 \%$ of the genera of all aquatic macroinvertebrates may be midges (Rodrìguez-Lozano et al., 2015). Even in places where the local fauna is quite well known, it is impossible to use larval morphology to produce a complete list of species (Lencioni et al., 2012; Tóth et al., 2013). Usually only genera or groups of species may be identified (Syrovátka \& Brabec, 2010). Moreover, pupal skins are an excellent material to be used to identify species, sometimes even more than adults, especially in areas where an identification key exists, as is the case in Europe (Langton \& Visser, 2000). Moreover, the use of DNA for species identification is becoming more and more prominent in modern taxonomy (Cranston \& Krosh, 2012; Anderson et al., 2013), phylogenetic studies (Ekrem et al., 2007; Cranston et al., 2010) and in biomonitoring (Carew et al., 2013). In addition, in the genus Chironomus species identification requires the use of polytene chromosomes (Pfenninger et al., 2007).

In most studies of population dynamics, trophic relationships and biomonitoring, larvae of the Chironomidae are identified only to family or subfamily level. If we consider that in one river site up to 100 species of Chironomidae may be found, it is obvious that plenty of information is lost (Rieradevall \& Prat, 1986a). Keys for the genera of larval instars of chironomids are available in the Holartic (Saether et al., 2000) or Paleartic regions (Wiederholm, 1983, 1986; Andersen et al., 2013), but species keys only exist for some genera. We have published several papers on the chironomid larvae of Spanish Mediterranean river basins (Puntí et al., 2007, 2009), with a total of 125 identified taxa, mostly at genera level, especially in very similar morphological genera (e.g., Cricotopus and Orthocladius). In other parts of the world the fauna of Chironomidae is less known, and if keys are provided for larvae or pupae, several unknown morphologies appear at the genus level, so there are many genera to describe as adults (Cranston, 2000; Prat et al., 2014). As a result, most papers list many unknown morphotypes (Acosta \& Prat, 2010; Roque et al., 2010).

As the collection, preparation and identification of pupal exuviae is relatively easy (Wiederholm, 1986); chironomid biodiversity studies tend to be based on collections of drift samples, where pupal exuviae are abundant (Rieradevall \& Prat, 1986a; Langton \& Casas, 1999; Lencioni et al., 2007; Garcia \& Añón-Suárez, 2007). The same is true in studies relating chironomid communities to pollution (Wilson, 1993) or other disturbances (Raunio et al., 2007). However, as not all 
the Chironomidae present in a site emerge at the same time, the species list obtained with the pupal skin collections is always incomplete (Raunio et al., 2007). Very few studies consider larvae and pupal exuviae at the same time (Ruse, 1995; Barton et al., 1996), and usually in such studies researchers use the few pupae or pupal exuviae found in benthic samples as a way to identify the larvae present in a specific site (Tang et al., 2010; Chaib et al., 2013). This is a time consuming task and, therefore, not many published papers can be found that use both larvae and pupal exuviae.

In the present study, samples of larvae and pupal exuviae were collected at the same time in eight river basins in NE Spain. Our main objective is to provide a list of the taxa found and to compare both types of inventories (larvae $v s$ pupae) to discuss the advantages of such binary collections. Our first hypothesis is that with the exuviae we should find more taxa than with the larvae, due to the fact that we can distinguish most of the species within a genus. However, we also hypothesize that not all taxa found, as larvae will appear in the pupal exuviae collection, due to differences in emerging periods among taxa, which can balance the total taxa found in each instar.

\section{Materials and methods}

We collected samples of larvae and pupal exuviae in 25 sites in Catalonia (NE Spain) in three seasons: spring, summer and autumn
(Table 1) with a total of 38 samples, in which both larvae and pupae were found. We use the acronyms listed in Table 1 for the sites in the text, tables and the Annex of this paper. All the sites were barely disturbed Mediterranean streams (Sanchez-Montoya et al., 2009), the physico-chemical parameters are those typical of near- pristine streams (Toro et al., 2002); therefore, changes in communities are not caused by human disturbance (Puntí et al., 2007, 2009).

Samples of pupal skins were taken with a hand net with a mesh size of 250 microns, using the chironomid pupal exuviae technique (CPET) field protocol. This method entails searching for exuviae in areas of the river where foam had previously accumulated (Rieradevall \& Prat, 1986b; Raunio et al., 2007) and in other areas where the exuvia may accumulate (e.g., emerged macrophytes). For larvae we followed the sampling method described in the Guadalmed protocol (Jaimez et al., 2002), using a hand net of 250 microns; in this case intensive sampling was carried out and macroinvertebrate families identified in the field. Several samples were taken until no new families of macroinvertebrates appeared. Samples were preserved in formalin (4\%) and transported to the laboratory. All the pupal exuviae were sorted, examined, classified to the genera level under the stereoscope and at least 10 individuals of each genera or morphotype were prepared for observation under the microscope. For larvae, between 100 and 602 individuals (Table 2) were sorted and observed under the stereoscope. Larvae were initially identified following the morphotype key of Prat \& Rieradevall (2014). All the larvae of the least abundant morphotypes were mounted onto slides,

Table 1. Location of sampling stations where samples of chironomid pupal exuviae and larvae of Chironomidae were collected.

\begin{tabular}{|c|c|c|c|c|c|c|c|}
\hline Basin & Site & UTM X & UTMY & $\begin{array}{l}\text { Altitude } \\
\text { (m a.s.I) }\end{array}$ & Stream & Province & $\begin{array}{l}\text { Watershed area } \\
\qquad\left(\mathrm{km}^{2}\right)\end{array}$ \\
\hline Anoia & AN01 & 881550 & 4606550 & 454 & Riera de Carme & Tarragona & 55.25 \\
\hline Besos & B24 & 924550 & 4628550 & 601 & Riera de Caldes & Barcelona & 2.75 \\
\hline Besos & B29 & 941550 & 4642550 & 809 & Riera d’Avencó & Barcelona & 6.25 \\
\hline Fluvia & FU01 & 953550 & 4698550 & 474 & Riera de Beget & Girona & 59.50 \\
\hline Fluvia & FU02 & 961550 & 4695550 & 338 & Río Llierca & Girona & 170.75 \\
\hline Fluvia & FU03 & 985550 & 4686550 & 61 & Río Fluvià & Girona & 877.5 \\
\hline Francoli & BR01 & 846550 & 4581550 & 531 & Riu Brugent & Tarragona & 57.00 \\
\hline Llobregat & L104 & 885550 & 4667550 & 696 & Río Aigua d'Ora & Barcelona & 89.75 \\
\hline Llobregat & L105 & 923550 & 4651550 & 674 & Riera de Postius & Barcelona & 12.25 \\
\hline Llobregat & L42 & 890550 & 4647550 & 341 & Río Cardener & Barcelona & 785.25 \\
\hline Llobregat & L54 & 903550 & 4687550 & 875 & Río Llobregat & Barcelona & 139.5 \\
\hline Llobregat & L60 & 903550 & 4670550 & 514 & Río Llobregat & Barcelona & 537.25 \\
\hline Llobregat & L61 & 913550 & 4664550 & 540 & Riera de Merlès & Barcelona & 119.5 \\
\hline Llobregat & L67 & 905550 & 4650550 & 323 & Río Llobregat & Barcelona & 956.5 \\
\hline Muga & MU01 & 995550 & 4714550 & 204 & Río Orlina & Girona & 19.25 \\
\hline Muga & MU02 & 989550 & 4714550 & 314 & Riera d'Anyet & Girona & 21.75 \\
\hline Ter & TE01 & 936550 & 4707550 & 1517 & Río Ter & Girona & 10.5 \\
\hline Ter & TE02 & 943550 & 4706550 & 1271 & Río Ritort & Girona & 4.75 \\
\hline Ter & TE03 & 939550 & 4677550 & 1001 & Río Ges & Girona & 12.75 \\
\hline Ter & TE04 & 930550 & 4677550 & 617 & Río Ter & Girona & 823.25 \\
\hline Ter & TE05 & 928550 & 4649550 & 755 & Río Meder & Barcelona & 14 \\
\hline Ter & TE06 & 966550 & 4662550 & 152 & Río Ter & Girona & 1928.25 \\
\hline Tordera & TO01 & 947550 & 4638550 & 660 & Río Tordera & Barcelona & 15.25 \\
\hline Tordera & TO02 & 953550 & 4639550 & 1264 & Riera de Gualba & Barcelona & 2 \\
\hline Tordera & TO03 & 465322 & 4617474 & 103 & Riera de Fuirosos & Barcelona & 15 \\
\hline Calonge & TL01 & 998550 & 4652550 & 157 & Torrente de Calonge & Girona & 4.25 \\
\hline
\end{tabular}


while at least 10 larvae were prepared for the most abundant ones. The slide mounting was done following Epler (2001) using Euparal $\odot$ as the mounting medium. Pupal exuviae were prepared in a similar way but without the previous treatment with $10 \%$ potassium hydroxide. All the slides and samples are part of the authors' personal collection.

\section{Results}

A total of 1589 exuviae were collected belonging to a total of 101 taxa (Tables 2 and 3). In Annex we provide the complete list and for each taxon the following information: the sampling sites, the period of the

Table 2 Percentage and number of genera and species of larvae and pupal exuviae of the midges subfamilies present in rivers studied.

\begin{tabular}{|c|c|c|c|c|c|c|}
\hline & $\begin{array}{c}\text { Larvae } \\
\%\end{array}$ & $\begin{array}{c}\text { Pupal exuviae } \\
\%\end{array}$ & $\begin{array}{l}\text { Larvae } \\
\text { Genera }\end{array}$ & Taxa & $\begin{array}{l}\text { upal exuvit } \\
\text { Genera }\end{array}$ & Spp. \\
\hline Tanypodinae & 7.83 & 0.57 & 10 & 10 & 3 & 5 \\
\hline Buchonomyiidae & 0.05 & 0.00 & 1 & 1 & - & - \\
\hline Diamesinae & 5.41 & 5.98 & 2 & 5 & 2 & 2 \\
\hline Prodiamesinae & 0.24 & 0.00 & 1 & 1 & - & - \\
\hline Orthocladiinae & 67.00 & 68.72 & 30 & 52 & 16 & 60 \\
\hline Chironominii & 5.40 & 2.52 & 7 & 13 & 7 & 12 \\
\hline Tanytarsinii & 14.08 & 22.22 & 9 & 18 & 8 & 22 \\
\hline Total & 7129 & 1589 & 60 & 100 & 36 & 101 \\
\hline
\end{tabular}

Table 3. Percentage of pupal exuviae and larvae and number of species of exuviae and taxa of larvae at each site. Relative importance of aggregated data of the genera Cricotopus $(\mathrm{C})$, Orthocladius $(\mathrm{O})$ and Paratrichocladius $(\mathrm{P})$ is also indicated.

\begin{tabular}{|c|c|c|c|c|c|}
\hline Basin & Site & $\begin{array}{c}\text { Pupal Exuviae } \\
\%\end{array}$ & $\begin{array}{l}\text { Pupal Exuviae } \\
\text { Species }\end{array}$ & $\begin{array}{c}\text { Larvae } \\
\%\end{array}$ & $\begin{array}{c}\text { Larvae } \\
\text { Taxa }\end{array}$ \\
\hline Anoia & AN01 & 0.06 & 1 & 2.71 & 12 \\
\hline Besos & B24 & 4.55 & 20 & 2.37 & 29 \\
\hline Besos & B29 & 0.55 & 4 & 2.15 & 13 \\
\hline Brugent & FR1 & 0.06 & 1 & 1.95 & 26 \\
\hline Fluvia & FU01 & 6.34 & 17 & 4.33 & 25 \\
\hline Fluvia & FU02 & 1.54 & 11 & 2.07 & 24 \\
\hline Fluvia & FU03 & 13.48 & 28 & 6.36 & 33 \\
\hline Llobregat & L104 & 0.43 & 6 & 1.31 & 20 \\
\hline Llobregat & L105 & 0.25 & 3 & 4.63 & 24 \\
\hline Llobregat & L42 & 1.54 & 5 & 3.49 & 17 \\
\hline Llobregat & L54 & 1.66 & 4 & 5.03 & 17 \\
\hline Llobregat & L60 & 0.37 & 6 & 4.78 & 33 \\
\hline Llobregat & L61 & 1.97 & 12 & 4.33 & 21 \\
\hline Llobregat & L67 & 5.35 & 19 & 3.80 & 24 \\
\hline Muga & MU01 & 16.37 & 30 & 4.38 & 27 \\
\hline Muga & MU02 & 4.06 & 10 & 5.22 & 29 \\
\hline Ter & TE01 & 0.12 & 2 & 3.36 & 15 \\
\hline Ter & TE02 & 0.43 & 4 & 4.5 & 24 \\
\hline Ter & TE03 & 13.42 & 19 & 3.5 & 21 \\
\hline Ter & TE04 & 9.97 & 31 & 5.23 & 24 \\
\hline Ter & TE05 & 0.12 & 2 & 2.65 & 20 \\
\hline Ter & TE06 & 14.89 & 23 & 4.90 & 22 \\
\hline Tordera & T001 & 0.12 & 4 & 6.82 & 17 \\
\hline Tordera & TO02 & 0.43 & 3 & 1.73 & 23 \\
\hline Tordera & T003 & 0.31 & 4 & 1.85 & 18 \\
\hline \multirow[t]{2}{*}{ Calonge } & TL01 & 1.35 & 3 & 6.57 & 22 \\
\hline & Total & & 101 & & 100 \\
\hline$\% \mathrm{C}+\mathrm{O}+\mathrm{P}$ & & 32.32 & & 25.64 & \\
\hline
\end{tabular}


year [spring (P), summer $(\mathrm{V})$ and autumm (0)] and the number of exuviae collected. In most of the species (47\%) a single skin was found, while the maximum number of exuviae found for one species in a site was 132 . In 13 sites less than 10 individuals were collected and in only four cases the number of total exuviae collected was more than 200 (Table 2). The number of taxa per site varied between 1 and 31, and there is a clear relationship between the number of individuals collected and the number of species found (Figure 1).

The complete list of larvae collected in the studied sites can be found in Puntí et al. $(2007,2009)$. The total number of larvae collected at the 25 sites sampled was 7129 from which more than 2000 were prepared on slides (not all were mounted because some can be identified under the stereoscope). When comparing the percentage of pupal exuviae in each chironomid subfamily with those of larvae, we found differences in the dominance of the different subfamilies (Table 3 ). While the Orthocladiinae are dominant both as larvae (67\%) and pupal exuviae (68.72\%), Tanytarsinii are relatively more abundant as pupal exuviae and Tanypodinae are nearly inexistent as pupal exuviae (Table 2). Comparing individual sites we found that only when at least 200 exuviae were collected, the number of taxa as pupae and larvae were similar (Table 3 ).

The number of genera is much higher for larvae (60) than for pupal exuviae (36) (Table 3). The number of genera with a unique taxon is slightly larger in the larvae (71.66\%) than in the pupal exuviae (62.6\%), while the number of species per genus is higher in the pupal exuviae (2.69 vs 1.76) (Table 4). The genera Cricotopus + Orthocladius + Paratrichocladius, were the most dominant, both in pupal exuviae (32.32\% of the individuals collected) and in larvae (25.64\%) (Table 2). As exuviae we found up to 15 species of Orthocladius, for example, that we were unable to distinguish as larvae using the current keys (except for the subgenus Euorthocladius, Table 4). The same is true for Cricotopus. In the case of Eukiefferiella a similar number of taxa were found as larvae and exuviae (but not the exact species list). We compared the taxa richness of one sample with more than 200 pupal exuviae collected (site MU1) and found that the total number of taxa was similar ( 28 as exuviae and 25 as larvae). There were more unique larval genera (30) than unique pupal exuviae genera (3). Thirty-two genera were common in both types of inventories.

\section{Discussion}

Chironomid scientists tend to use pupal exuviae collections to study the biodiversity of this group of Diptera. The adults are usually used only to name the species, but not for large inventories of biodiversity. The collection, preparation and identification of a given species are easier with the pupal exuviae than with the adults. Moreover, pupal exuviae are gaining prominence for their use in applied methods, such as biomonitoring (Ruse \& Davison, 2000). The advantages and disadvantages of the use of pupal exuviae and the CPET technique were synthesized by Raunio \& Muotka (2005) and Raunio et al. (2007). One of the main problems of collecting floating pupal exuviae is that sometimes, with this technique, only few individuals are collected, as was our case in some sites. Why we found so few pupae in some sites is not clear, because we used a similar time of sampling in all sites. Perhaps, as most of the sites are in reference condition, there are few places for pupal skin retention. In spring low temperatures had prevented most of the species to emerge as adults. In any case, it is clear that with this set of data conclusions should be considered with caution.

In our study we found 60 genera as larvae and only 36 as pupae, while the final number of taxa was 100 and 101 despite the difference in the individuals examined (1589 pupal exuviae vs 7129 larvae). Therefore, we need 121 larvae or 44 pupae to find one genus and 71 larvae $v s 16$ pupae to identify one taxon. Our first hypothesis was that we must find more taxa in the exuviae collection than in the larvae, because we are able to distinguish more species. If we look at the total number of taxa collected the hypothesis is disproven because both numbers are similar. But if we correct the taxa number for the number of individuals, with the same number of individuals taken as pupae, we should find only a total of 22 taxa or 13 genera as larvae (if the increase of taxa was linear with the individuals captured). However, such linear relationships do not exist, because as is shown in Figure 1, after 200 individuals the number of taxa of pupae slowly increases. In addition, larvae live on the substrate for months, while pupae exuviae disappear after only few days in water, especially if the temperature is high. Taken together, the above considerations show that our first hypothesis is not true, which is partly due to the fulfilment of the second hypothesis. If we take into consideration that some of the larval genera that may provide many species have not been classified to species or species group, our larval collection might even produce a larger number of species than the exuvial pupae surface floating collections. In addition, the number of genera present as larvae was much higher, which is quite normal because not all larvae present at a given site emerge at the same time. Therefore, our second hypothesis is correct because many genera present in the riverbed as larvae were not present in the pupal exuviae collected (up to 30 genera, nearly $50 \%$ of the total genera collected in both insect stages).

Drift samples provide more species than the CPET technique, although more sampling time is required (Raunio \& Muotka, 2005). In an extensive study with drift samples, Calle-Martínez \& Casas (2007) found up to 204 species in 39 sites, as did Langton \& Casas (1998). In an intensive survey ( $24 \mathrm{~h}$ taking consecutive drift samples at one hour intervals), Rieradevall \& Prat (1986a) found 62 species in the Llobregat River in one sampling station. The same authors, i.e., Rieradevall \& Prat (1986b), using the CPET technique, found 86 species in 17 sites along the same river. However, as indicated previously, our results should be taken with some caution due to the small number of individuals collected in some sites, which may partly be a result of the insufficint training of the field assistants than to the CPET method itself. In the future the use of massive sequencing techniques will result in larger larval species lists than the collections of pupal exuviae. This will be very useful for many studies, including for biomonitoring (Baird and Hajibabaei, 2012; Woodward et al., 2013).

We conclude that for measuring the biodiversity of midges in rivers, both types of samples should be collected (collecting approximately 200 pupal exuviae at each site); until all larvae are univocally identified using barcoding.

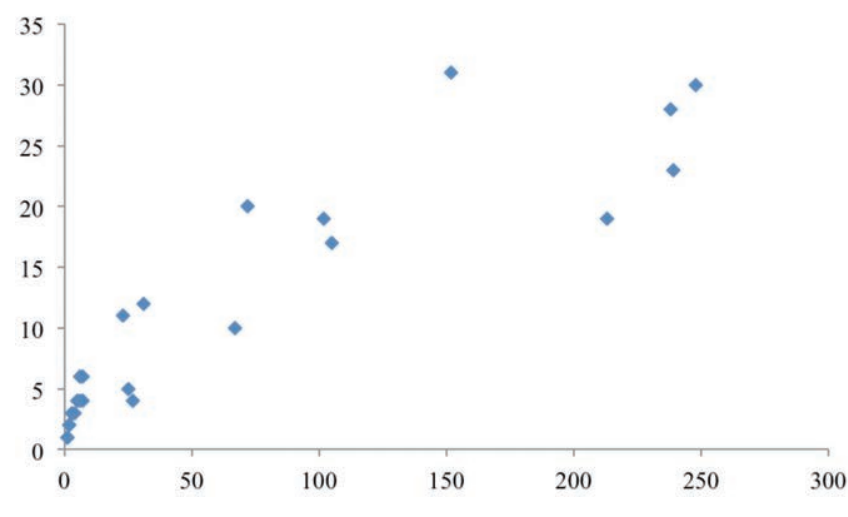

Figure 1. Relationship between the number of individuals captured as pupal exuviae (abscissa) and the taxa present (ordinate). 
Table 4. Number of taxa within each genus as larvae and pupal exuviae. The total number of genera and the relative importance of the genera with only one species is also indicated together with the mean number of taxa per genera.

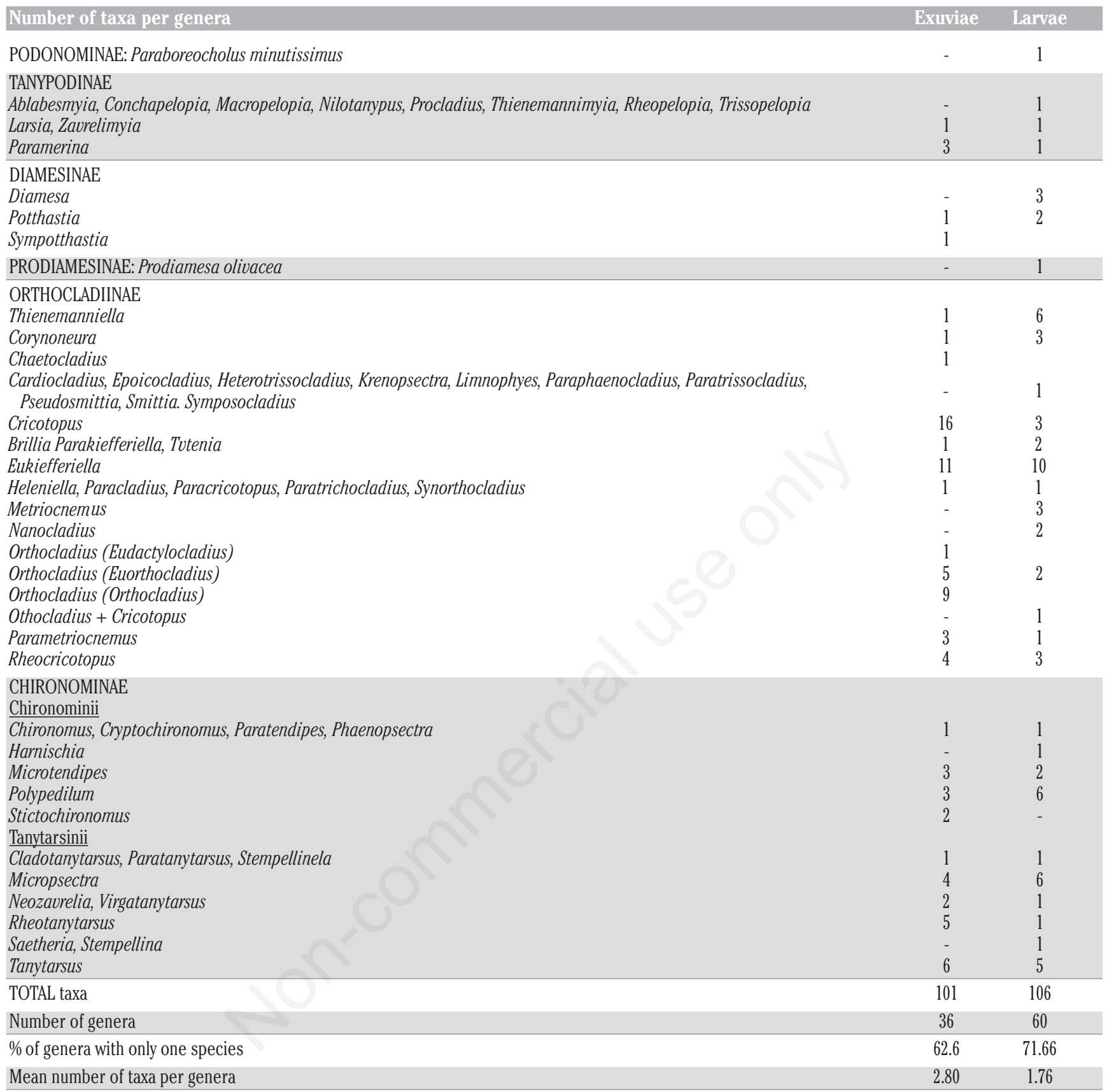

\section{References}

ACOSTA R., PRAT N., 2010 - Chironomidae assemblages in high altitude streams of the Andean region of Peru. - Fundam. Appl. Limnol. 177: 57-79.

ANDERSEN T., CRANSTON P.S., EPLER J.H. (eds.), 2013 - The larvae of Chironomidae (Diptera) of the Holartic Region. Keys and diagnoses. - Insect Syst. Evol. Suppl. 66: 1-571.

ANDERSON A.M., STUR E., EKREM T., 2013 - Molecular and morphological methods reveal criptic diversity and three new species of Neartic Micropsectra (Diptera: Chironomidae). - Freshwater Sci. 32: 892-921.

ARMITAGE P., CRANSTON P.S., PINDER L.C.V. (eds.), 1995 - The
Chironomidae. The biology and ecology of nonbiting midges. Chapman and Hall, London: 572.

BAIRD D.J., HAJIBABAEI M., 2012 - Biomonitoring 2.0: a new paradigma in ecosystem assessment made possible by next-generation DNA sequencing. - Mol. Ecol. 21: 2039-2044.

BARTON D.R., OLIVER D.R., DILLON M.E., 1996 - A comparison of pupal exuviae and larval Chironomidae of the impacts of agricultural practices on surface water quality. In: CRANSTON P. (Ed.), Chironomids: from genes to ecosystems. - CSIRO Publications, East-Melbourne: 125-132.

CALLE-MARTINEZ D., CASAS J.J., 2007 - Chironomid species, stream classification, and water quality assessment: the case of 2 Iberian Mediterranean mountain regions. - J. North Am. Benthol. Soc. 25: $465-476$. 
CAREW M.E., PETTIGROVE V.J., METZELING L., HOFFMANN A.A., 2013 - Environmental monitoring using next generation sequencing: rapid identification of macroinvertebrate bioindicator species. Front. Zool. 10: 45.

CHAIB N., BOUHALA Z., FOUZAR L., MARZALI L., SAMRAOUI B., ROSSARO B., 2013 - Environmental factors affecting the distribution of Chironomid larvae of the Seybouse wadi, North-Eastern Algeria. - J. Limnol. 72: 203-214.

CRANSTON P.S., 2000 - The electronic guide of Chironomidae of Australia. - Available from: http://apes.skullisland.info/node/3

CRANSTON P.S., HARDY N.B., MORSE G.E, PUSLEDIK L., MCCLUEN S.R. 2010 - When molecules and morphology concur: the "Gondwanan" midges (Diptera: Chironomidae). - Syst. Ecol. 35: 635-648.

CRANSTON P.S., KROSCH M., 2011 - Barbadocladius Cranston, Krosch, a new genus of Orthocladiinae (Diptera: Chironomidae) from South America. - Neotrop. Entomol. 40:560-567.

EPLER J., 2001 - Identification manual for the lñarval Chironomidae (Diptera) of North and South Carolina. A guide to the taxonomy of the midges of southeastern United States, including Florida. North Carolina Department of Environment and Natural Resources, Raleigh, NC and St. Johns River Water Management District, Plalatka, FL. Special Publication SJ2011-SP13: 526.

EKREM T., WILLASSEN E., STUR E., 2007 - A comprehensive DNA sequence library is essential for identification with DNA barcodes. - Mol. Phylogen. Evol. 43: 530-542.

FERRINGTON JR.L.C., 2008 - Global diversity of non-biting midges (Chironomidae; Insecta-Diptera) in freshwater. - Hydrobiologia 595: 447-455.

GARCIA P.E., AÑÓN-SUÁREZ D.A., 2007 - Community structure and phenology of chironomids (Insecta: Chironomidae) in a Patagonia Andean stream. - Limnologica 37: 109-117.

HIRABAYASHI K., YAMAMOTO M., YAMAMOTO M., KIMURA G., 2010 Seasonal trends in populations of chironomid midges in the high mountain Nishina Three Lakes in Japan. - Verh. Internat. Verein. Limnol. 30: 1433-1438.

JÁIMEZ-CUÉLLAR P., VIVAS S., BONADA N., ROBLES S., MELLADO A., ÁLVAREZ M., AVILÉS J., CASAS J., ORTEGA M., PARDO I., PRAT N., RIERADEVALL M., SÁINZ-CANTERO C.E., SÁNCHEZ-ORTEGA A., SUÁREZ M.L., TORO M., VIDAL-ALBARCA M.R., ZAMORA-MUÑOZ C., ALBA-TERCEDOR J., 2002 - Protocolo GUADALMED (PRECE). Limnetica 21: 187-204.

LANGTON P., CASAS J., 1999 - Changes in chironomid assemblage composition in two Mediterranean mountain streams over a period of extreme hydrological conditions. - Hydrobiologia 390: 37-49.

LANGTON P.H., VISSER H., 2003 - Chironomidae Exuviae. A key to the pupal Exuviae of West palaearctic region. - Expert Centre for Taxonomic Identification, University of Amsterdam, Amsterdam.

LENCIONI V., MARZIALI L., ROSSARO B., 2012 - Chironomids as bioindicators of environmental quality in mountain springs. Freshwater Sci. 31: 525-541.

LENCIONI V., ROSSARO B., MAIOLINI B., 2007 - Alpine chironomid distribution: a mere question of altitude? In: ANDERSEN T. (ed.), Contributions to the sytematics and ecology of aquatic Diptera. A tribute to Ole A. Saether. - Caddis Press, Columbus, 0H: 165-180.

PFENNINGER M., NOWAK C., KLEY C., STREIT B., 2007 - Utility of DNA taxonomy and barcoding for the inference of larval community structure in morphologically cryptic Chironomus (Diptera) species. - Mol. Ecol. 16: 1957-1968.

PRAT N., GONZÁLEZ-TRUJILLO J.D., OSPINA-TORRES R., 2014 - Clave para la determinación de exuvias pupales de los quironómidos (Diptera: Chironomidae) de ríos altoandinos tropicales. - Rev. Biol. Trop. 62: 1385-1406.

PRAT N., RIERADEVALL M., 2014 - Guia para el reconocimiento de las larvas de Chironomidae (DIPTERA) de los ríos mediterráneos. Versión 1 - Diciembre 2014. Grup de recerca F.E.M. (Freshwater Ecology and Management). - Universitat de Barcelona. 29 pp. (F.E.M. Guies. Volum 3). Available from: http:/hdl.handle.net/2445/60584

PUNTÍ T., RIERADEVALL M., PRAT N., 2007 - Chironomidae assemblages in reference condition Mediterranean streams: environ- mental factors, seasonal variability, and ecotypes. - Fund. Appl. Limnol. 170: 149-165,

PUNTÍ T., RIERADEVALL M., PRAT N., 2009 - Environmental factors, spatial variation, and specific requirements of Chironomidae in Mediterranean reference streams. - J. North Am. Benthol. Soc. 28: 247-265.

RAUNIO J., MUOTKA T., 2005 - The use of chironomid pupal exuviae in river biomonitoring: the importance of sampling strategy. - Arch. Hydrobiol. 164: 529-545.

RAUNIO J., PAAVOLA R., MUOTKA T., 2007 - Effects of emergence, phenology, taxa tolerances and taxonomic resolution on the use of Chironomidae Pupal Exuvial Technique in river biomonitoring. Freshwater Biol. 52: 165-176.

RIERADEVALL M., PRAT N., 1986a - Diel pattern of chironomid drift in the Llobregat River (N.E. Spain). - Oecol. Aquat. 8: 61-70.

RIERADEVALL M., PRAT N., 1986b - Quironómidos de la deriva del río Llobregat: Composición y algunos datos sobre su uso como indicadores biológicos. - Actas VIII Jornadas Asociación Española de Entomologia: 811-820.

RODRÍGUEZ-LOZANO P., VERKAIK I., RIERADEVALL M., PRAT N., 2015 - Small but powerful: top predator local extinction affects ecosystem structure and function in an intermittent stream. - PLoS One 10: $\mathrm{e} 0117630$.

ROQUE F.O., SIQUEIRA T., BINI L.M., RIBEIRO M.C., TAMBOSI L.R., CIOCHETI G., TRIVINHO-STRIXINO S., 2010 - Untangling associations between chironomid taxa in Neotropical streams using local and landscape filters. - Freshwater Biol. 55: 847-865.

RUSE L.R., 1995 - Chironomid community structure deduced from larvae and pupal exuviae of a chalk stream. - Hydrobiologia 315: 135-142.

RUSE L., DAVISON M., 2000 - Long-term assessment of chironomid taxa structure and function in the river Thames. - Regul. Rivers 16: 113-126.

SÁNCHEZ-MONTOYA M.M., VIDAL-ABARCA M.R., PUNTÍ T., POQUET J.M., PRAT N., RIERADEVALL M., ALBA-TERCEDOR J., ZAMORAMUNÑOZ C., TORO M., ROBLES S., ÁLVAREZ M., SUAÁREZ M.L., 2009 - Defining criteria to select reference sites in Mediterranean streams. - Hydrobiologia 619: 39-54.

SAETHER O.A., ASHE P., MURRAY D.A., 2000 - Chironomidae. In: PAPP L. and ARVAS B.D. (eds.), Manual of Paleartic Diptera. - Science Herald, Budapest: 113-334.

SYROVÁTKA V., BRABEC K., 2010 - The response of chironomid assemblages (Diptera Chironomidae) to hydraulic conditions: a case study in a gravel-bed river. - Fund. Appl. Limnol. 178: 43-57.

TANG H., SONG MI-Y., CHO W-S., PARK Y-S., CHON T-S., 2010 - Species abundance distribution of benthic chironomids ans other macroinvertebrates across different levels of pollution in streams. - Ann. Limnol. 46: 53-66.

TORO M., ROBLES S., AVILÉS J., NUÑO C., VIVAS S., BONADA N., PRAT N., ALBA-TERCEDOR J., CASAS J., GUERRERO C., JÁIMEZ-CUÉLLAR P., MORENO J.L., MOYÁ G., RAMON G., SUÁREZ M.L., VIDALABARCA M.R., ÁLVAREZ M., PARDO I., 2002 - Calidad de las aguas de los ríos mediterráneos del proyecto Guadalmed. Características físico-químicas. - Limnetica 21: 63-75.

TÓTH M., ÁRVA D., NAGY S.A., SPECZIÁR A., 2013 - Species diversity and abundance of plant dwelling chironomids across hierarcicla habitat and seasonal scales in the owbow lakes of river Tisza, Hungary. - Fund. Appl. Limnol. 184: 309-321.

WIEDERHOLM T. (ed), 1983 - Chironomidae of the Holoarctic region. Key and diagnoses. Part I: Larvae. - Entomol. Scand. Suppl. 19: 457.

WIEDERHOLM T. (ed.), 1986 - Chironomidae of the Holarctic region. Part 2 Pupae. - Entomol. Scand. Suppl. 28: 482.

WILSON R.S., 1993 - Monitoring organic enrichment of rivers using chironomid pupal exuvial assemblages. - Netherland J. Aquat. Ecol. 26:521-525.

WOODWARD G., GRAY C., BAIRD D.J., 2013 - Biomonitoring for the 21st century: New perspectives in an age of globalisation and emerging environmental threats. - Limnetica 32: 159-174. 


\section{Appendix: Maria Rieradevall}

Last October $15^{\text {th }}$, the professor of Ecology of the Department of Ecology of the University of Barcelona, Maria Rieradevall passed away. She started her studies analysing Chironomidae exuviae from the Llobregat River, and soon after began her PhD thesis about the benthos of the Banyoles Lake under the supervision of Prof. Dr. Narcís Prat. She continued her research working on the taxonomy of Chironomidae and the study of the ecology of Mediterranean rivers. More recently, she focused on intermittent rivers in the Iberian Peninsula, being one of the first to consider the joint effect of drought and fire on aquatic macroinvertebrates. She was also involved in several projects to design biomonitoring tools to assess the ecological status of Mediterranean

\section{Annex}

Pupal exuviae collected in Catalan rivers. For each taxa the sampling sites codes and the sampling dates are listed in Table 1. P = spring; $\mathrm{V}=$ summer; 0 = autumn. The number of specimens found is also indicated. Pex $=$ Pupal exuviae.

\section{TANYPODINAE}

Larsia curticalar (Kieffer 1918) MU1P, 3Pex.

Paramerina divisa (Walker, 1856) BR1V, 1Pex.

Paramerina cingulata (Walker, 1856) MU10, 2Pex.

Paramerina sp. FU2P, 1Pex.

Zavrelimyia barbatipes (Kieffer, 1911) B240, 1Pex. MU1P, 1Pex.

\section{DIAMESINAE}

Potthastia gaedii (Meigen 1838), FU3P, 14Pex. L67P, 1Pex. L670 6Pex. MU1P, 42Pex. TE6P, 1Pex

Sympotthastia spinifera Pagast 1947. B240, 6Pex; FU1P, 3Pex. MU1P, 18Pex. MU10, 5Pex; TL1P, 1Pex.

\section{ORTHOCLADIINAE}

Corynoneura group

Thienemanniella sp. TE2P, 1Pex. TE4V, 2Pex.

Corynoneura spp. B290, 1Pex. FU1P, 1Pex. FU3P, 2Pex. L600, 1Pex. Mu2P, 1Pex

Other Orthocladiinae

Brillia bífida (=modesta) Kieffer, 1909. TE6P 2Pex

Chaetocladius melaleucus (Meigen 1818). B240, 1Pex.

Cricotopus (Cricotopus)bicinctus (Meigen 1818). FU3P, 2Pex; L670, 16Pex; TE6P, 5Pex.

Cricotopus (C.) curtus Hirvenoja 1973. L610, 4Pex.

Cricotopus (C.) festivellus (Kieffer, 1906). L670, 1Pex

Cricotopus (C.) flavocinctus (Kieffer, 1924). B240 14Pex.

Cricotopus (C.) fuscus Kieffer 1909. B240, 8Pex. FU2P, 2Pex; Fu3P 4Pex. L610, 2Pex. L670, 12Pex. MU1P, 1Pex. MU2P, 1Pex. TE3P 6Pex; Te4P, 2Pex. TE6P, 6Pex.

Cricotopus (C.) near levantinus. FU2P, 1Pex.

Cricotopus Pe. 8 Langton 1991. TE3P, 1Pex.

Cricotopus Pe 9 Langton 1991. FU3P, 2Pex. L670, 4Pex.

Cricotopus (C.) similis Goetghebuer 1921. FU1P, 1Pex; FU2P, 1Pex. TE4P, 1Pex.VV3I, 1Pex.

Cricotopus (C.) tremulus (Linnaeus, 1758). FU1P, 8Pex. FU2P, 3Pex. TE4P, 9Pex. TE40, 1Pex.

Cricotopus (C.) triannulatus (Macquart, 1826). FU3P, 1Pex. and Andean rivers. She always kept her interest in lentic environments, especially in coastal lagoons and mountain lakes. Her experience on Chironomidae communities was very valuable when studying paleolimnological records to explore the past to understand the present. Along her research career, she supervised 23 Bachelor/Master, $5 \mathrm{PhD}$, and 2 ongoing $\mathrm{PhD}$ theses and trained a generation of very enthusiastic researchers who are following her paths. She will be remembered by her contributions to the Iberian limnology but also by her passion for docent activities, scientific outreach, and her rigour and creativity in whatever she was involved. For more details see: BONADA N., CAÑEDO-ARGÜELLES M., CID N., OBRADOR B., RODRÍGUEZ-LOZANO P., VERKAIK I., 2015 - In memoriam: Maria Rieradevall (1960-2015). Limnetica. 34: i-vi.

Cricotopus (C.) trifascia Edwards, 1929. FU3P, 1Pex.

Cricotopus (C.) tristis Hirvenoja 1973. L670, 8Pex.

Cricotopus (C.) vierriensis Goetghebuer, 1935. B240 3Pex. FU3P, 2Pex. L104P, 1Pex; L610, 1Pex, L670, 1Pex, TE20, 1Pex. Te4P, 1Pex. TE4V, 2Pex. TE40, 1Pex.

Cricotopus (I.) sylvestris (Fabricius, 1794) B240, 3Pex

Cricotopus( I.) trifasciatus (Meigen in Panzer, 1813). L60R0, 1Pex.

Ekiefferiella brehmi Gouin 1943. B240, 2Pex. TE2P, 4Pex. TE3P, 3Pex.

Eukieferiella brevicalcar (Kieffer, 1911). B290, 1Pex. MU1P, 8Pex. MU2P, 6Pex

Eukieferiella claripennis (Lundbeck, 1898). B240, 2Pex. MU1P, 1Pex.

Eukieferiella clypeata (Kieffer, 1923). FU1P, 1Pex. FU3P, 1Pex. MU1P 2Pex. TE4V 1Pex.

Eukieferiella coerulescens (Kieffer in Zavrel, 1926).TL1P, 1Pex.

Eukieferiella devonica (Edwards, 1929). L610, 2Pex. TE1P, 1Pex.

Eukieferiella gracei (Edwards, 1929). FU2P, 1Pex. FU3P, 3Pex. L42P, 1Pex. L610, 5Pex. TE1P, 1Pex. TE30, 1Pex.

Eukieferiella ilkleyensis (Edwards, 1929). FU1P, 1Pex. FU3P, 4Pex. TE0, 1Pex.

Eukieferiella minor-fittkaui B290, 2Pex. TE3P, 1Pex.

Eukieferiella tirolensis Goetghebuer, 1938. TL1P, 3Pex.

Eukieferiella pe2 Langton 1991. L610, 3Pex.

Heleniella serratoisoi Ringe 1976. MU2P, 2Pex.

Orthocladius (Eudactylocladius) fuscimanus Kieffer, in Kieffer \& Thienemann, 1908). B240, 3Pex.

Orthocladius (Euorthocladius) ashei Soponis, 1990. TE4P, 16Pex. TE40, 4Pex.

Orthocladius (Euorthocladius) luteipes Goetghebuer, 1938. Mu10, 2Pex. TE4P, 11Pex.

Orthocladius (Euorthocladius) rivicola Kieffer, 1921. FU1P, 2Pex. MU1P, 1Pex. TE3P, 44Pex. TE4P, 6Pex. TE40, 2Pex. TE6P, 1Pex.

Orthocladius (Euorthocladius) rivulorum Kieffer, 1909. MU10, 1Pex. MU2P, 1Pex. TE6P, 2Pex

Orthocladius (Euorthocladius) thienemanni Kieffer in Kieffer \& Thienemann, 1906. AN10, 1Pex.

Orthocladius (Orthocladius) frigidus (Zetterstedt, 1838). FU2P, 1Pex.MU1P, 1Pex. TE4P, 1Pex-

Orthocladius (Orthocladius) glabripennis (Goetghebuer, 1921). TE40, 1 Pex.

Orthocladius (Orthocladius) oblidens (Walker, 1856). FU1P, 4Pex. FU3P, 5Pex. L540, 1Pex. L60R0, 1Pex.L610, 1Pex. L67P, 1Pex. L670, 22Pex. MU1P, 13Pex. TE40, 5Pex. TE6P, 38Pex. TE60, 1Pex.

Orthocladius (Orthocladius) obumbratus Johannsen, 1905. B240, 2Pex. FU1P, 6Pex. L670, 1Pex. MU1P, 1Pex. TE3P, 1Pex. TE4P, 7Pex. TE40, 1Pex. 
Orthocladius (Orthocladius) pedestris Kieffer, 1909. MU1P, 2Pex. L670, 1Pex. TE3P, 1Pex. TE4P, 1Pex

Orthocladius (Orthocladius) rivinus Kieffer, 1915. B240, 1Pex. FU1P, 2Pex. FU2P, 2Pex. L1040, 2Pex.

Orthocladius (Orthocladius) rubicundus (Meigen, 1818). FU1P, 62Pex. FU2P 11Pex. FU3P 6Pex. L42P, 21Pex. L600, 1Pex. L610, 8Pex. L67P, 1Pex. L670, 10Pex. MU1P, 35Pex. MU2P, 20Pex. MU20, 1Pex. TE3P, 3Pex. TE30, 1Pex. TE4P, 28Pex., TE40, 7Pex. TE6P, 121Pex., T020, 1 Pex.

Orthocladius (Orthocladius) wetterensis L670, 1Pex.

Orthocladius (Orthocladius) pe7 Langton. FU3P, 1Pex.

Orthocladius (Orthocladius) pe8 Langton. TE3P, 2Pex.

Paracladius conversus (Walker, 1856). TE4P, 1Pex.

Paracricotopus niger (Kieffer, 1913). FU1P, 6Pex. L104V, 1Pex. L420, 1Pex. TE3P, 2Pex. TE4P, 1Pex. TE4P, 1Pex. TE6P, 2Pex. TE4P, 2Pex. T01V, 1Pex.

Parakiefferiella nigra T01V, 1Pex.

Parametriocnemus borealpinus Gouin in Gouin \& Thienemann, 1942. B240, 1Pex. FU1P, 1Pex. TE5P, 1Pex. T02V, 2Pex.

Parametriocnemus stylatus (Kieffer, 1924). FU3P, 7Pex. L1050, 2Pex. MU2P, 2Pex. TL1P, 1Pex. T03P, 1Pex

Paratrichocladius rufiventris (Meigen, 1830).FU3P, 5Pex. L105P, 1Pex. L61P, 1Pex. L670, 5Pex. MU1P, 2Pex. MU2, 29Pex. TE4P, 1Pex. TE40, 2Pex. TE40, 2Pex. TE6P, 12Pex.

Rheocricotopus atripes (Kieffer, 1913). B24V, 2Pex, B240, 16Pex. FU3P, 2Pex. TE4V, 2Pex. TE60, 1Pex.

Rheocricotopus chalybeatus (Edwards, 1929). FU1P, 1Pex. FU3P, 88Pex. TE4P, 2Pex. TE40, 1Pex. TE6P, 3Pex.

Rheocricotopus effusus (Walker, 1856). TL1P, 2Pex.

Rheocricotopus fuscipes (Kiefer, 1909). L105P, 1Pex. L600, 1Pex. MU1P, 5Pex. TE3P, 3Pex. TL1P, 6Pex.

Synorthocladius semivirens (Kieffer, 1909). MU1P, 1Pex. TE40, 1Pex.

Tvetenia calvescens (Edwards, 1929). B290, 1Pex. FU3P, 14Pex. L600, 1Pex. L610, 3Pex, TE4P, 2Pex. TE4V, 1Pex. TE6P, 18Pex. TL1P, 2Pex. T01V, 2Pex. T03P, 1Pex

\section{CHIRONOMINAE}

Chironominii

Chironomus spp. B240, 1Pex. L67P, 1Pex. T01V, 2Pex. Cryptochironomus rostratus Kieffer, 1921. TE6P, 1Pex.

Microtendipes brittenni (Edwards, 1929)B24V, 2Pex. FU3P, 3Pex. L670, 2Pex.
Microtendipes pedellus (De Geer, 1766). B24V, 2Pex. TE3P, 1Pex. Microtendipes rydalensis (Edwards, 1929). FU1P, 1Pex

Paratendipes albimanus (Meigen, 1918). TE3V, 1Pex. TE6P, 1Pex. Phaenopsectra flavipes (Meigen, 1818). L670, 1Pex. TE6P, 1Pex. Polypedilum albicorne (Meigen, 1838). MU1P, 1Pex. TE30, 1Pex. TE4P, 1 Pex.

Polypedilum convictum (Walker, 1856). FU1P, 2Pex. TE4P, 2Pex.

Polypedilum cultellatum Goetghebuer, 1931. TE6P, 11Pex.

Stictochironomus maculipennis (Meigen, 1818). L61P, 1Pex

Stictochironomus ?stictulus (Fabricius, 1794). L420, 1Pex.

Tanytarsinii

Cladotanytarsus pe 8 Langton. Te6P, 3Pex.

Micropsectra atrofasciata (Kieffer, 1911). B240, 1Pex. FU3P, 17Pex. L670, 2Pex. MU1P, 74Pex. TE4P, 2Pex. TE40, 1Pex. TE6P, 3Pex.

Micropsectra lindrothi Goethghebuer in Goetghebuer and Lindroth, 1931. TE2P, 1Pex.

Micropsectra ?logani. L540, 5Pex.

Micropsectra pallidula. TL1P, 1Pex. T03P, 2Pex

Neozavrelia fuldensis Fittkau, 1954. TE4P, 3Pex.

Neozavrelia sp. L540, 20Pex. FUP, 3Pex. L670, 1Pex. TE3P, 132Pex.

Paratanytarsus dissimilis Johanssen, 1905. FU3P, 32Pex. L670, 2Pex. MU1P, 3Pex.

Rheotanytarsus curtistylus (Goetghebuer, 1921). L1040, 1Pex.

Rheotanytarsus pellucidulus T01V, 1Pex.

Rheotanytarsus reissi Lehmann, 1970. L1040, 1Pex.

Rheotanytarsus rhenanus Klink, 1983. FU3P, 1Pex. TE4P, 3Pex. TE40, 1 Pex.

Rheotanytarsus cf rioensis Langton \& Armitage, 1995. TE3P, 2Pex.

Stempellinela flavidula (Edwards), T03P, 1Pex

Tanytarsus chinyensis Goetghebuer, 1934. $\mathrm{FU}<\mathrm{p}, 2 \mathrm{Pex}$.

Tanytarsus ejuncidus (Walker, 1856). FU3P, 8Pex. MU1P, 9Pex. TE6P. 2 Pex.

Tanytarsus gibbosciceps Kieffer. B240, 1Pex.

Tanytarsus heusdensis Geotghebuer, 1923. TL1P, 3Pex.

Tanytarsus multipunctatus Brundin. FU3P, 7Pex. MU1P, 3Pex.

Tanytarsus signatus (Van der Wulp, 1858). MU1P, 5Pex. Virgatanytarsus sp 2 Langton FU2P, 1Pex. Virgatanytarsus sp. TE6P 2Pex. 